\title{
Bifurcated homeland and diaspora politics in China and Taiwan towards the Overseas Chinese in Southeast Asia
}

\author{
Enze Han ${ }^{\mathrm{a}, \mathrm{b}^{*}}$ \\ ${ }^{a}$ Department of Politics and Public Administration, University of Hong Kong, Hong Kong; ${ }^{b}$ Department of \\ Politics and International Studies, SOAS, University of London, London, UK
}

\begin{abstract}
The conventional literature on diaspora politics tends to focus on one 'homeland' state and its relations with 'sojourning' diaspora around the world. This paper examines an instance of 'bifurcated homeland:' the People's Republic of China and the Republic of China (Taiwan) since 1949. The paper investigates the changing dynamics of China's and Taiwan's diaspora policies towards Overseas Chinese communities in Southeast Asia throughout the Cold War and post-Cold War periods. They were affected by their ideological competition, the rise of Chinese nationalism, and the 'indigenisation' of Taiwanese identity. Illustrating such changes through the case of the KMT Yunnanese communities in Northern Thailand, this paper makes two interrelated arguments. First, we should understand relations through the lens of interactive dynamics between international system-level changes and domestic political transformations. Depending on different normative underpinnings of the international system, the foundations of regime legitimacy have changed. Subsequently, the nature of relations between the diaspora and the homeland(s) transformed from one that emphasises ideological differences during the Cold War, to one infused with nationalist authenticity in the post-Cold War period. Second, the bifurcated nature of the two homelands also created mutual influences on their diaspora policies during periods of intense competition.
\end{abstract}

\section{KEYWORDS}

Homeland-diaspora relations; diaspora policy changes; China; Taiwan; Overseas Chinese; KMT

\section{Introduction}

In the mountain town of Mae Salong, located in Thailand's northernmost Chiang Rai province bordering Myanmar, stands a memorial statue that states in Chinese,

After the Yunnan Kunming Incident of December 9, 1949, the celestial land turned red. Sons and daughters of Chinese people who could not tolerate Marxism, for lofty ideals and for survival, endured much hardship and ended up in the mountainous areas in the borderland area between Yunnan and Burma ${ }^{1}$, remaining there for several decades.

CONTACT Enze Han enzehan@hku.hk

*From January 2018, he will be Associate Professor, Department of Politics and Public Administration, University of Hong Kong, Pok Fu Lam, Hong Kong SAR, People's Republic of China.

(C) 2017 The Author(s). Published by Informa UK Limited, trading as Taylor \& Francis Group

This is an Open Access article distributed under the terms of the Creative Commons Attribution-NonCommercial-NoDerivatives License (http://creativecommons.org/licenses/by-nc-nd/4.0/), which permits non-commercial re-use, distribution, and reproduction in any medium, provided the original work is properly cited, and is not altered, transformed, or built upon in any way. 
Mae Salong, although in Thailand, is a town with a distinct Chinese character. Despite the prominent display of the Thai national flag, most of the street signs are in Chinese, and locals, especially the older generation, speak the Yunnan dialect of Chinese instead of Thai. Throughout the Northern Thai provinces of Chiang Mai, Chiang Rai, and Mae Hong Son, there are many such Chinese settlement villages, hosting remnants and descendants of Chinese Nationalist Kuomintang (KMT) troops resettled in Thailand in the early 1960s (Chang 2014). They are often referred to as Yunnanese Chinese, in contrast to other Chinese diasporas which came to Thailand via the sea from southern provinces of Guangdong, Fujian, and Hainan (Skinner 1957). These Yunnanese have a distinct political history that tied them to the Chinese Civil War, the ideological competition between the KMT and the Chinese Communist Party (CCP), and the People's Republic of China (PRC)'s rival regime - the Republic of China (ROC), or government in Taiwan ${ }^{2}$ (Duan 2008; Huang 2010).

This competition between rival regimes of the PRC and ROC in the aftermath of the Chinese Civil War meant the Chinese homeland became bifurcated for its diaspora communities around the world. Particularly during the Cold War, both Beijing and Taipei claimed itself as the sole representative of China, while denouncing the other as illegitimate. It was only in the recent past that this bifurcation has arguably come to an end. As a result of PRC's phenomenal economic growth and its diplomatic offensive, most countries in the world today recognise it as the only government of China. At the same time, the indigenisation of Taiwanese identity increasingly carries with it the de-emphasis of being Chinese. Therefore, most of the overseas Chinese community - except those with direct connection to Taiwan - have increasingly been left with only one 'homeland'.

This paper examines the evolution of diaspora policies between the two competing Chinas, and contributes to a theoretical discussion of diaspora management under the context of bifurcated homeland. The literature on diaspora politics tends to assume the existence of the origin state - the homeland - in a singular form. However, there are instances where this is not true - where the assumed homeland disintegrates into two or more parts. The Chinese case provides an excellent lens to study the phenomenon of bifurcated homelands, and theoretical implications for our understanding of state-diaspora relations and diaspora governance (Délano Alonso and Gamlen 2014; Gamlen 2014; Ho 2011; Ragazzi 2014).

The paper makes two interrelated arguments. First, it argues that we should understand state-diaspora relations through the interactive dynamics between international systemlevel changes and domestic political transformations. Depending on different normative underpinnings of the international system, from ideological competition during the Cold War to nationalism and identity politics after the Cold War, what constitutes the foundation of regime legitimacy have changed. Subsequently, the nature of relations between the diaspora and the homeland(s) changed from one that emphasises ideological differences to one infused with nationalist authenticity. During the Cold War when Communism vs. anti-Communism ideological differences separated the two competing regimes, Beijing and Taipei both approached the large Overseas Chinese community in Southeast Asia with strong instrumentality, intending to win their political loyalty to boost their own regime legitimacy. However, in the post-Cold War era when politics of identity and nationalism replaced previous ideological conflicts, it has become less tenable for Taiwan to sustain its claim of homeland for the Overseas Chinese. At the 
same time, its democratisation and indigenisation processes have ushered in a new form of regime legitimacy that emphasises the de-coupling from China, and the ensuring diaspora policy changes to focus more narrowly on overseas Taiwanese. On the other hand, Beijing's turn to nationalism post-1989 has framed the rising China as the sole legitimate protector of the Chinese diaspora with whom they should identify and support (To 2014). Thus, we have to approach state-diaspora relations and diaspora governance according to an understanding of international system changes and their subsequent implications for how states frame their relations with the diaspora communities, as required by changing foundations of regime legitimacy.

The second argument rests solely on the nature of bifurcated homeland, in that it creates a situation where both governments had mutual influences on their diaspora policies during periods of intense competition. Such policies were often made with one eye on what the other was doing. This means diaspora policy-making involves certain copying, mimicking, and even outbidding between rivals. It suggests this competitive dynamic might not be restricted to this extreme case of bifurcated homeland, and we should look for instances where countries are under a competitive logic that creates mutual influences in their policy-making towards diaspora.

Methodologically, the paper combines comparative case studies with ethnographic field research. After a brief review of existing literature on state-diaspora relations and diaspora governance in the context of a bifurcated homeland, the paper presents a brief historical background of the Chinese diaspora in Southeast Asia. Then the paper discusses the ideological competition between the PRC and ROC among the Overseas Chinese community in Southeast Asia during the Cold War. It then examines how post-Cold War nationalist developments in both Taiwan and China changed the dynamic of their respective policies towards the Chinese diaspora. The paper then proceeds with the case study of Yunannese Chinese in Northern Thailand to illustrate the micro-foundations of the argument. ${ }^{3}$ Research within the Yunnanese Chinese was conducted in the summers of 2015 and 2016. The author visited several of the major KMT settlement villages in northern Thailand, including Mae Salong, Tham Ngob, and Banmai Nongbour, where interviews were carried out. Additional interviews were also done via phones and emails with the KMT descendants who have migrated to China, Myanmar, and Taiwan. The paper concludes with some general reflections on the paper's theoretical contribution.

\section{Theories of bifurcated homeland diaspora governance}

Existing literature on diaspora politics almost always assumes the existence of a singular national homeland for diasporic communities (Safran 1991; Cohen 1996; Armstrong 1976). For example, in Safran's seminal work on the definition of diaspora, it was explicitly conceived as a group of people who have been dispersed from a specific original homeland (Safran 1991, 83). Although there have been attempts to broaden the definition of diaspora to include 'specific cases of groups that do not identify themselves or are not considered as such by their origin state' (Délano Alonso \& Mylonas, 2019), the assumption that diaspora originates and connects to a singular homeland in the form of a nation-state has often been implicitly held in the literature about diaspora politics and their relations with the homeland (Adamson 2006; Adamson and Demetriou 2007; Brinkerhoff 2009; Koinova 2009; Shain 2008). Yet, there are instances, though rare, where the so-called homeland 
has been fragmented into two or more competing parts, each of which claims itself as the legitimate representative body for the sojourning population (Panagiotidis 2015). Indeed, during the post-World War II (WWII) period, as a consequence of the emerging Cold War, there are at least four such instances where such bifurcation occurred, namely between the Republic of Korea (South Korea) and the Democratic People's Republic of Korea (North Korea) (1948), the Federal Republic of Germany (West Germany) and the German Democratic Republic (East Germany) (1949-1990), the Democratic Republic of Vietnam (North Vietnam), and the Republic of Vietnam (South Vietnam) (1955-1975), and Republic of China (Taiwan) and the People's Republic of China (1949-). However, what is unique about the Chinese case is that for much of the post-WWII period, both governments refused to accept the other as a legitimate counterpart while insisting on itself as the sole representative body of China (Eberstadt 2010; Metzler 2014; Stevenson 2001). To this day, neither government accepts mutual recognition, and diplomatic relations with one means automatic severance of such with the other, which is not the case with both East and West Germanys and North and South Koreas. Perhaps, we can argue there are some resemblance of the Chinese case to Paalberg's piece in this volume that looks at competitive outreach efforts by Salvadoran political parties to woo political support among the diaspora, in the sense that in the CCP vs. KMT rivalry, the extreme competition between the two political parties led to the breakup of the Chinese bodypolitic.

In diaspora studies, interests in diaspora governance tend to focus on how and why homeland states engage their diaspora communities through various strategies and institutions (Délano Alonso and Gamlen 2014; Gamlen 2014; Ragazzi 2014). For example, Ragazzi (2014) summarises three dominant accounts of diaspora politics. The first one is an instrumental interpretation that looks at how states reach out to their diaspora communities mainly for economic reasons (Itzigsohn 2000; Levitt and de la Dehesa 2003; Smith 2003). In the Asian context, such an instrumental rationale certainly manifests itself in how several states such as the Philippines, depend heavily on economic remittances from their transitional diaspora communities around the world (Parreñas and Siu 2007). In the Chinese case, its economic development since the late 1970s depended heavily on investments by Overseas Chinese communities throughout the Asia Pacific region (Lardy 1994; Seagrave 2010; Smart and Hsu 2004). The second account of diaspora politics resonates with transnational citizenship and the issue of identity among the dispersed population (Appiah 2007; Bosniak 2006; Joppke 1999; Skrbis 1999). Here, on the one hand there is a renewed debate on how diaspora communities should integrate with host communities under the context of multiculturalism (Fludernik 2003; Hesse and Sayyid 2000), but there are also instances where homeland states purportedly monitor and support the ethnonationalist expressions of their diasporas (Adamson 2013; Brubaker 1996; Mylonas 2013). Finally, there is the governmentality approach that looks at state relations with their diasporas through the lens of political-economic rationality and regimes (Gamlen 2013; Ho 2011; McConnell 2012; Mullings 2012; Ragazzi 2009). Subsequently, studies have increasingly focused on global migration governance (De Haas 2010; Gamlen 2010), on the interlinks between homeland states, diaspora communities, and international normative regimes, in terms of how diaspora institutions shape migrant subjects and how international ideas shape diaspora institutions' (Gamlen 2014, S194). Indeed, it seems there are more consensus that the diffusion 
of global norms of shared governance has stronger effect on how states approach their management of diasporas (Gamlen, Cummings, and Vaaler 2019).

In light of these different approaches, how can we understand the phenomenon of bifurcated homeland and its implications for explaining diaspora governance in the PRC/ROC case? This paper argues that the international system has undergone fundamental changes in its normative underpinnings moving from a period of ideological competition during the Cold War to a resurgence of nationalism and identity politics in the post-Cold War period (Buzan 2007; Hannerz and Goldmann 2000). Coinciding with such changes, the relationship between the diaspora and the two competing homelands also changed from one heavily defined by competing ideologies to one increasingly fused with ethnonationalist claims of identity and belonging, as foundations of regime legitimacy have changed.

\section{Overseas Chinese in Southeast Asia}

The Chinese ${ }^{4}$ have a long history of migration to Southeast Asia, and their migration experiences have had several distinct patterns. Generally speaking, first there were the Chinese traders huashang who went down to Nanyang (South Sea) for business, settled down locally and formed families there (Wang 1991, 5). Then there were Chinese coolie-laborer huagong who were recruited during colonial periods by Europeans to work in mines and plantations in certain parts of Sumatra and the Malay Peninsula (Wang 1991, 6). During the last days of the Qing Dynasty in late nineteenth century, the Manchu court claimed official protection of China's citizens abroad, which redefined Overseas Chinese as sojourning huaqiao whose loyalty should be towards China rather than the European colony. The 1909 Law of Nationality of the Qing set out a jus sanguinis principle that defined anyone born to either a Chinese father or mother as a Chinese citizen, and also granted dual citizenship to all Chinese and their descendants living abroad (To 2014, 54).

The Overseas Chinese community played a crucial role in the Republican Revolution that overthrew the Qing, with many revolutionary figures, such as the founding father of the ROC Sun Yat-sen, coming from abroad. More important was the fact that financing for the revolutionary cause was mostly provided by Overseas Chinese (Esman 1986, 133). After the founding of the ROC, the 1929 Nationality Law continued the jus sanguinis principle of the Qing, and granted citizenship to all ethnic Chinese around the world (Rigger 2002; Shao Dan 2009). Additionally, Overseas Chinese were officially included in various official bodies such as the Overseas Chinese Affairs Committee (OCAC) (Qiaowu Weiyuanhui), as well as in various branches of the KMT and its affiliate organisations (Nyíri 1997, 163). In addition, the KMT government actively promoted Chinese education in Southeast Asia through the establishment of Chinese schools, with the purpose of developing skills of Overseas Chinese so they could better serve the homeland (Fitzgerald 1972, 8).

In the post-WWII period when Southeast Asian states started their own decolonisation and nation-building processes, many of these Chinese sojourners acquired local citizenship, partly encouraged by the newly founded People's Republic of China so as to improve diplomatic relations with the respective Southeast Asian state. Subsequently they became people of Chinese descent living permanently abroad huayi, thus they no 
longer have Chinese citizenship (Wang 1991, 9). Finally, there are recent migrants during the past few decades from the PRC to Southeast Asia as well as around the world, termed xinyimin, who have or had PRC passports and migrated for business and work purposes.

The total number of diasporic Chinese in Southeast Asia is estimated at 30-40 million. ${ }^{5}$ Although this is a rough estimate, it is understood that ethnic Chinese have a sizable presence in many Southeast Asian countries, not to mention in the city-state of Singapore, where the majority population can be described as of Chinese descent. By now, the majority of Overseas Chinese in Southeast Asia have most likely acquired local citizenship. Often lacking access to political power, their middleman status in the local economies has made them vulnerable to discrimination and political repression (Suryadinata 2007). Also depending on inter-ethnic religious and cultural differences, some have intermixed and assimilated better than others, such as in the Philippines and Thailand, as opposed to Malaysia and Indonesia. See Table 1 for rough estimates of Overseas Chinese population in Southeast Asian countries, and their respective diplomatic relations with the PRC and the ROC since the end of the Second World War.

\section{Cold War: ideological competition between PRC and ROC}

When the Cold War descended on East Asia, the Chinese Civil War entered an abrupt impasse. Led by the United States, most western and other anti-communist countries supported the ROC government in Taipei as the legitimate representative of China, and Taipei was able to maintain its seat as the permanent member of the UN Security Council until 1971. On the other hand, the PRC faced initial diplomatic isolation, especially from the anti-Communist camp led by the United States. Thus, during the early years of the Cold War, both Beijing and Taipei deemed the other illegitimate while portraying themselves as the sole representative of China. Other than the diplomatic tug-of-war between the two, they competed head-on for loyalty of the Chinese diaspora in Southeast Asia (Oyen 2010).

For the PRC, due to connections with various Communist Parties in Southeast Asia, most of which recruited heavily from Overseas Chinese communities, the CCP had an

Table 1. Estimated numbers of overseas Chinese, and diplomatic relations of Southeast Asian countries with PRC and ROC during modern periods.

\begin{tabular}{|c|c|c|c|}
\hline Countries & $\begin{array}{l}\text { Estimated overseas Chinese } \\
\text { population }^{\mathrm{a}}\end{array}$ & $\begin{array}{l}\text { Diplomatic relationship with } \\
\text { PRC }\end{array}$ & $\begin{array}{l}\text { Diplomatic relationship with } \\
\text { ROC }\end{array}$ \\
\hline Brunei & $56,000(2006)$ & $1991-$ & N/A \\
\hline Cambodia & $150,000(2003)$ & $1958-$ & 1947-1958 \\
\hline Indonesia & 7.3 Million (2003) & $1950-$ & $1945-1950$ \\
\hline Laos & $50,000(2003)$ & $1961-$ & 1953-1962 \\
\hline Malaysia & 7.0 Million (2006) & $1974-$ & 1957-1974 \\
\hline Myanmar & 1.3 Million (2003) & $1950-$ & $1948-1950$ \\
\hline Philippines & 1.5 Million (2004) & $1975-$ & 1948-1975 \\
\hline Singapore & 2.7 Million (2005) & $1990-$ & 1965-1990 \\
\hline Thailand & 8.5 Million (2006) & $1975-$ & $1945-1975$ \\
\hline Vietnam & 2.3 Million (2006) & $1950-$ & With South Vietnam 1955-1975 \\
\hline
\end{tabular}

${ }^{\mathrm{a}}$ The numbers presented are very rough estimates because not every country carry out census including the number of ethnic Chinese, and also it is extremely difficult to determine who is Chinese and who is not, given varying degrees of intermarriages and assimilation in different countries in Southeast Asia. The data from this column are retrieved from the New World Encyclopedia entry on Overseas Chinese. http://www.newworldencyclopedia.org/entry/Overseas Chinese\#cite_note-22. 
interest in exporting and promoting revolution. Thus the Party's International Liaison Office (wailianbu) continued to maintain close connection with left-leaning elements of the Chinese diaspora (Chen 1994). On the other hand, the new government in Beijing also needed the Overseas Chinese community for economic assistance and post-Revolution reconstruction and modernisation.

Beijing initially continued the jus sanguinis doctrine that included the Overseas Chinese into the remit of its political protection. The National Census of 1953 included Overseas Chinese as part of the population of China, recorded at around 11.7 million. ${ }^{6}$ The National People's Congress also included representatives from the diaspora (Esman 1986, 135). The government also promised protection of Overseas Chinese' family members' properties in China, while encouraging remittances and investments from abroad. For the new government, these remittances formed a big source of badly needed foreign currency (Zhuang 1998). In terms of education, the PRC carried out special recruitment of Overseas Chinese to study in the mainland. It provided grants, and waived minimum education qualifications for many students (Fitzgerald 1972, 128). This education outreach was partly motivated by the need to compete with the KMT, as the CCP claimed itself as the symbol of the new China that represented Chinese people around the world; but it was also due to the fact there were many Southeast Asian Chinese youth voluntarily returned to China with enthusiasm for the new political order (Fitzgerald 1972, 129).

However, the diplomatic isolation that the Beijing government faced also forced it to seek good relations with Southeast Asian neighbours. One of the main obstacles was the citizenship status of many members of the Chinese diaspora. Several post-independence Southeast Asian governments held suspicions about loyalty of the Chinese community and whether they would become a fifth column for Chinese foreign policy interference (Fitzgerald 1972). Because of the need to placate suspicious Southeast Asian governments, Beijing changed its jus sanguinis citizenship policy. At the Bandung Afro-Asian Conference in 1955, the Chinese Premier Zhou Enlai proclaimed that China was willing to negotiate with Southeast Asian governments on the nationality and citizenship status of Overseas Chinese (Fitzgerald 1972). Subsequently in the SinoIndonesian Dual Nationality Treaty of 1955, the PRC officially abandoned the jus sanguinis principle, stipulating that Overseas Chinese should have the freedom to choose Indonesian or Chinese citizenship, adding that if they chose Indonesian citizenship they would not be able to claim the Chinese one (Esman 1986, 135). The Beijing government encouraged Overseas Chinese to choose local citizenship for the purpose of promoting good relations between itself and its Southeast Asian neighbours (Fitzgerald 1972, 142). The treaty with Indonesia set a precedent for the other Southeast Asian countries. Since then, other than those who returned to China both voluntarily and involuntarily, most Overseas Chinese acquired local citizenship, and thus no longer had a legal connection with the Mainland.

Domestic political radicalisation since the mid 1950s unleashed significant changes in the PRC's policies towards the Chinese diaspora. Early preferential treatments for the Overseas Chinese and their family members in China were stopped. Instead, people with external links became targets of oppression on suspicion of being class enemies or agents of imperialism (To 2014, 66). Especially during the Cultural Revolution, much of the government bureaucracy dealing with Overseas Chinese affairs ceased to function. The Overseas Chinese Affairs Commission was dissolved in 1968. Also during this 
period, many Overseas Chinese and their family members who had recently returned left China once again. For example, about 400,000 re-emigrated between 1967 and 1972 (To $2014,65)$. On the other hand, the Party doubled its efforts to promote revolution abroad, specifically targeting Southeast Asia. Beijing started to actively support Communist insurgencies in Southeast Asia, many of which heavily recruited from the Overseas Chinese population (Chin 2003).

Across the Strait in Taiwan, the KMT government also presented itself as the legitimate government, while the mainland was deemed occupied by 'Communist bandits'. Overseas Chinese were crucial for the KMT government because they could provide legitimacy for its claim to areas larger than Taiwan (Damm 2012, 220). As the government only had de facto control of Taiwan itself, it had to rely on a claim that it represents the whole of China, including the Overseas Chinese, to justify itself as still the legitimate Republic of China government rather than just the government of Taiwan (Wang 2011, 83). Thus, even though most of the Overseas Chinese' ancestors came from the mainland and had nothing to do with the island of Taiwan, the KMT government pushed for the idea that the ROC was the ancestral homeland for the whole of Chinese diaspora. In October 1952, the ROC government organised the first Global Overseas Chinese Affairs Convention (quanqiu qiaowu huiyi), and designated 21 October as the Overseas Chinese Day. An non-governmental organisation Federation of Overseas Chinese Association (huaqiao jiuguo lianhe zonghui) was created for the purpose of maintaining close contact with Overseas Chinese communities, promoting Overseas Chinese growth, and using the support of the Overseas Chinese to maintain the survival and development of the ROC government. ${ }^{7}$

One crucial emphasis of the KMT government to solicit support from Overseas Chinese was anti-Communist ideology. Using the slogan 'Overseas Chinese are the mothers of Revolution (huaqiao wei gemin zhimu)', referencing the crucial support they gave to the Republican Revolution, it emphasised its alliance with the anti-Communist countries, such as the United States, Thailand, the Philippines, and others in Southeast Asia, and portrayed itself as the bearer of republicanism and democracy, in contrast to the Communist government in Beijing (Wang 2011, 71). In several Southeast Asian countries with strong anti-Communist orientations, this managed to win support among sections of the Overseas Chinese community who were anti-Communist, or, at least, were fearful of being branded as Communist sympathisers. ${ }^{8}$

In the area of education, Taipei also competed with Beijing. With financial support from the United States, who deemed Taipei's educational outreach to the Overseas Chinese as beneficial for its overall anti-Communism strategy in Southeast Asia, the ROC government provided generous scholarships as well as other special treatment to attract Overseas Chinese to study in Taiwan (Wong 2016, 349). Taipei supported language and educational training in Overseas Chinese communities, including providing textbooks, educational supplies, and offering summer camps and cultural activities in Taiwan (Wang 2011, 78-79). The purpose of course was to establish the ROC's legitimacy in the eyes of the Overseas Chinese as the 'free Chinese alternative to Communism and as a free world partner in the defense against Communist expansion in Asia' (Wang 2011, 78). Such efforts resemble what Israel's provision of educational trip for Jewish youth to Israel (Abramson, this volume), as well as the state sponsored homeland-tour for overseas Moroccan youths (Mahieu 2019). In addition, when the Cultural Revolution was wreaking havoc in the PRC, the ROC government initiated a Cultural Renaissance Movement 
(wenhua fuxing yundong), which portrayed Taiwan as symbol and keeper of traditional and authentic Chinese culture (Chun 1994). Such messages were heavily promoted among the Overseas Chinese community to demonstrate the authenticity (zhonghua zhi zhengtong) of the ROC as the real motherland for all the Chinese diaspora.

The ROC government maintained the jus sanguinis principle. As the continuation of its 1929 Nationality Law, Overseas Chinese can claim ROC citizenship, even though they might already have foreign citizenship. Additionally, the ROC government provided political representation for Overseas Chinese. In order to demonstrate the ROC government truly represented the whole of China, not just Taiwan, representatives from overseas Chinese communities were elected to the National Assembly (Rigger 2002).

\section{Post-Cold War: rising nationalism in China, and democratisation in Taiwan}

In post-Mao China, economic development and modernisation became the fundamental priority for the CCP. When Deng Xiaoping presided over economic reform, the overseas Chinese once again became the source of needed investment to jumpstart China's economic development. The Overseas Chinese Affairs Office (qiaoban) of the State Council was re-established in 1978, and the All-China Federation of Returned Overseas Chinese Associations (qiaolian) resumed work in the same year (To 2014, 69). Instead of relying on the overseas Chinese for revolutionary regime legitimacy, the Party now explicitly wanted them to support China's modernisation.

But this set of policies really blossomed following the end of the Cold War. Beijing mobilised resources to attract overseas Chinese for tourism, study, and investment. It set up preferential policies to do so. The 1990 Law Protecting Rights and Interests of Overseas Chinese and Their Relatives provided the legal assurance that Overseas Chinese and their interests in China would be protected. Again in 2000, Beijing made further amendments to the 1990 law, including

protection of their remittances, farms, houses and properties; guidance, and support of their donations, investments, and contributions; clauses welcoming their return to China and for settlement; promoting their participation in China's modernization; facilitation of their employment; encouragement of youth to study and the elderly to settle down in China; and also simplification of their entry/exit by ensuring speedy approval and a warm reception.

(To 2014, 71-72)

The effects of such welcoming policies were striking, as Overseas Chinese investment has played a key role in China's strong economic growth (Gao 2003; Smart and Hsu 2004).

Another motivation behind the intensification of diaspora policies was the 1989 Tiananmen Incident. The CCP government faced an unprecedented crisis and international pressure at the time. In order to prevent Overseas Chinese from opposing the CCP's rule in China, Beijing intensified its propaganda to win them over (Nyíri 1997; To 2014). Many delegates were sent out to meet with Overseas Chinese communities around the world to explain the situation in China. Beijing also set up numerous mass organisations to liaise with Overseas Chinese communities (Nyíri 2006). It is during this post-Tiananmen period that the CCP government intensified its promotion of nationalism domestically through implementing the Patriotic Education programme from the early 1990s (Wang 2008; Zhao 1998). To compensate for the loss of legitimacy of the Communist ideology 
in the post-Cold War period, nationalism became the rallying cry for Beijing (Gries 2004; Weiss 2014). Coinciding with phenomenal economic growth, Beijing's outreach campaign targeted Overseas Chinese to showcase the achievements China had made (Hartig 2016; Kurlantzick 2007). The discourse of the 'rise of China' was utilised to instil pride of the motherland among the Overseas Chinese. The Chinese government also established Confucius Institutes to promote the learning of Chinese language and culture around the world, with specific emphasis on the Overseas Chinese community (Hartig 2012; Hoare-Vance 2010). Diplomatically, Beijing has outcompeted Taipei in terms of international recognition, and as a result, various Overseas Chinese communities have gradually switched from identifying with the ROC to the PRC.

On the other hand, as a result of the democratisation process in Taiwan since the 1990s, and the coming to power of the pro-Taiwan independence Democratic Progressive Party (DPP) in 2000 (Dittmer 2004; Niou 2004), Taiwan has undertaken steps to sever its connection to mainland China (Makeham and Hsiau 2005). The democratic transition unleashed a major wave of identity politics, as well as the indigenisation of political representation (Chang and Holt 2014; Lee and Williams 2014). Heated debates occurred domestically regarding Overseas Chinese representation in the National Assembly, and whether voting rights should be extended to them (Hughes 1997). Extending voting rights would be consistent with the ROC jus sanguinis principle, but it be unfair for the local population in Taiwan, who are outnumbered by Overseas Chinese (Low 2013, 272-273). In the end, through a series of laws in the 1990s, the ROC government limited full citizenship rights, including the right of residence, work and suffrage, to ROC nationals with permanent household registration in Taiwan (Low 2013, 281). Although Taipei did not terminate jus sanguinis per se, and continued to regard Overseas Chinese, including PRC Chinese, as its nationals, their citizenship rights on the island were heavily restricted.

More fundamental was the change of national identification of the population in Taiwan, which distanced them from being 'Chinese'. Ever since the Lee Teng-hui presidency in the 1990s, but more so since Chen Shui-bian became first DPP president in 2000, domestically in Taiwan there has been a significant push to de-sinicise Taiwan ( $q u z-$ hongguohua) (Hughes 2011). There has been strong popular demand to change the name of the country from ROC to Taiwan, and the pro-Taiwan Independence Movement has gained popular support with time, partly aided by the rise of the PRC and its diplomatic isolation of Taiwan. Such identity changes on the island translate into fundamental redefinition of Taiwan's relations with the diaspora, namely from the previous Overseas Chinese (huaqiao) to Overseas Taiwanese (taiqiao), emphasising links with the Island of Taiwan (Damm 2012). According to the new definition, many Overseas Chinese who do not have ancestral relationships with Taiwan would be excluded from Taiwan's diaspora policy. Indeed, the previous Overseas Chinese Affairs Commission changed its name to Overseas Compatriot Affairs Commission in 2006, dropping all reference to 'Chinese'. The name changed again to Overseas Community Affairs Council in 2012.

Therefore, in the post-Cold War period, as a result of domestic political and economic changes in both PRC and ROC, the meaning and utility of Overseas Chinese fundamentally changed. In contrast to the PRC's renewed effort to solicit loyalty and support, the ROC government has taken steps to distance itself from the traditional set of overseas Chinese. These all occurred as a result of domestic political transformations in both 
China and Taiwan, and the changes in their respective regime legitimacy. In order to illustrate the dynamics in the context of a bifurcated homeland, the following section examines a critical case, that of KMT Yunnanese communities in Northern Thailand, to describe the micro-foundation of this transformation and how it has affected the politics of belonging among the overseas Chinese.

\section{The KMT Yunnanese communities in Northern Thailand}

When the People's Liberation Army (PLA) entered the southwestern Yunnan province in early 1950, a section of the KMT army retreated south and crossed the border into what was then Burma, now Myanmar. The Communist victory in China, together with military developments in the Korean War (1950-1953), led to a change of US strategic priorities in East Asia to the containment of Communism (Bresnan 1994; Guan 2001; Olson and Roberts 2013). As a result, the United States decided to support the KMT troops in Burma, hoping to militarily harass the Chinese communist regime in its Southwest borderland and thereby divert attention from Korea. After repeated protests by the Burmese government and under international pressure, since 1953, several rounds of retreat of these soldiers and their families were carried out. Many chose to settle in the borderland area between Thailand and Burma, with more than 80 villages in Chiang Mai, Chiang Rai, and Mae Hong Son. ${ }^{9}$ Most of these people have been associated with the 3rd and 5th Army, under the leadership of Li Wenhuan and Duan Xiwen, respectively (Chang 2008; Huang 2010). As a result of this turbulent history, these Yunnanese Chinese have held strong anti-Communist views towards Beijing, and kept close association with Taiwan (Hill 1998). For them, their homeland, at least until very recently, has been unquestionably the ROC in Taiwan.

Throughout the Cold War, their close connection with the ROC government in Taiwan meant they had unquestionable loyalty towards the KMT government. Since the 1980s, the ROC's Chinese Association for Relief and Ensuring Services (zhonghua jiuzhu zonghui) provided them assistance in terms of Chinese language education and economic development. ${ }^{10}$ Specifically in terms of education, Taiwan provided textbooks, teachers, and teacher training for local schools, from primary to high school levels. The ROC government also certified these schools, so that students graduating from them were qualified for university entrance in Taiwan, if they passed the Overseas Examination (haiwai lianzhao). ${ }^{11}$ These villages have also been occasionally visited by ROC government officials as part of their Overseas Chinese/Compatriot work, because this is a community which arguably has been the most loyal towards the ROC.

After the PRC and Thailand established diplomatic relations in 1975, other Overseas Chinese communities in Thailand reconnected with the Chinese mainland (Siriphon 2016). However, KMT Yunnanese communities in Northern Thailand were the last to reconcile with Beijing because of their peculiar history. However, in 2006 the Chinese Consul-General Peng Rendong made a visit to two such villages in Chiang Mai where he made donations to local schools. ${ }^{12}$ This event was interpreted by the ROC government, under DDP president Chen Shui-bian, as a betrayal by the local Yunnanese community. Taiwan subsequently cut educational assistance to the schools that hitherto received donations (Chen 2010). Without such support, those schools eventually turned to the PRC consulate for support, which led the PRC government to officially sponsor them 
with books and financial assistance. However, this incident created significant division within the Yunannese villages as to how to deal with the outreach from the PRC, as well as with the historical enmity and rivalry of the two Chinese governments (Siriphon 2016).

Such controversies highlighted tension within these communities. As part of the DPP government's effort to de-Sinicise Taiwan, it further cut off education assistance to the Chinese schools in Northern Thailand. For the DPP, these communities represented links with its archrival the KMT, and so were legacies of the KMT's One-China claim, and in essence they had little to do with Taiwan. Thus, the fact that the communities in Northern Thailand reached out to the PRC provided an excellent excuse for the DPP government to justify their actions. On the other hand, the domestic indigenisation and proTaiwan independence movement have also become unacceptable to hardcore ROC supporters in Northern Thailand. Ultimately, the country they fought for was the Republic of China that represented the authentic and traditional China, but not for Taiwan as an independent country.

Interviews with some of these KMT Yunnanese people confirmed such seismic changes in their perception of the PRC and the ROC. One such person is Laosi. ${ }^{13}$ His family history is typical of the complexities of migration, borderland warfare, and changing relations between the PRC and ROC. Born in Burma in the early 1960s, Laosi is the youngest of four children. When he was four, he came to Thailand with his family and they settled in a KMT village in Chiang Mai. His parents left Yunnan with the KMT troops, leaving behind his oldest sister, who still lives in their hometown in Yunnan. His second sister went to Taiwan for study, but later moved to Shanghai for business. She has lived in the PRC for more than 10 years. The other brother also went to Taiwan for study, and has remained there since. There are thus multiple citizenships and allegiances in Laosi's family. Both his parents remain stateless, though they have permanent residency in Thailand. His oldest sister is in Yunnan, so naturally she has PRC citizenship. Both Laosi's two siblings went to Taiwan for study and have ROC passports. Laosi never went to Taiwan for study, so he stayed in Thailand and obtained a Thai passport - though only in the 1980s.

For Laosi, even though he grew up in Thailand and speaks Thai, he went through the ROC funded Chinese education system and thus identifies strongly as ethnically Chinese. At the same time, he and his family are overwhelmingly against the idea of Taiwanese independence recently introduce in the ROC. He said,

I am not suggesting Mainland China and Taiwan should unite. I do not think both sides are ready for that. The future of cross-Strait relations will be decided by later generations. However, I strongly believe in the Republic of China, and that both the Mainland people and the Taiwanese people are Chinese.

Such opinions are quite commonly heard among the KMT Yunnanese in Northern Thailand. They might not really have accepted the PRC's version of China, but they are certainly against the pro-independence movements within Taiwan, and fear the danger of demise of the Republic of China as a political concept.

When asked what he thinks is his homeland (zuguo), Laosi replied with a sarcastic chuckle,

for us Yunnanese growing up in the borderland between Burma and Thailand, we have no homeland. My parents are from Yunnan, but I was born and grew up in Burma and Thailand. 
We have been taught at school that we are Chinese and the Republic of China is our homeland, and Communist China is the enemy. But now cross-Strait relations are relatively stable, and Mainland China has developed so fast and become so powerful that as Overseas Chinese, we want peaceful relations between the two sides.

The old ideological enmity between the PRC and the ROC no longer holds much traction among the Yunnanese in Northern Thailand. In its stead, there is a willingness to work with and benefit from the PRC's economic growth.

Indeed, these days the deepening economic relations between PRC and Thailand have significantly improved job prospects for people who can speak Chinese and Thai. In 2015 alone, there were almost eight million tourists from China to Thailand. ${ }^{14}$ Furthermore, Chinese investment in Thailand has burgeoned for the past few decades. As a result, there is a huge demand for people with bilingual skills, for which KMT Yunnanese are at a huge advantage, due to the long existence of Chinese education in their communities. In addition, because of the Chinese fascination with the peculiar wartime migration history of the Yunnanese in Northern Thailand, some settlement villages, such as Mae Salong, have become popular tourist destinations. In an ironic way, the old anti-Communist KMT villagers have become the loyal nationalists that the PRC is actively courting.

\section{Conclusion}

The peculiar case of a bifurcated homeland between the PRC and ROC provides us with an excellent example to probe how states devise their diaspora policies and governance. Because of changes in regime legitimacy during and after the Cold War, when competing ideologies were overtaken by divergent nationalist imaginations, what we find is a redefinition of the diaspora, in terms of the differentiation of overseas Taiwanese away from overseas Chinese in Taiwan. In the case of KMT Yunnanese communities in Northern Thailand, their wartime migration history had tied them closely to the ROC government in Taiwan. Yet as a result of domestic changes in Taiwan, the previous ideological rivalry can no longer sustain their identification with the ROC as the authentic China.

Therefore, this paper suggests the need to be attuned to international system-level changes from the Cold War to the post-Cold War periods, from an emphasis on ideology to identity. Such system-level changes subsequently ushered in domestic transformations that have generated different trajectories of diaspora policies in both China and Taiwan. In order to understand state-diaspora relations and diaspora governance, we have to pay attention to international system-level changes and their subsequent implications for domestic politics. In The Domestic Abroad, Varadarajan (2010) argues that global economic integration provokes forceful reassertion of national identity and drives the attitudinal and institutional production and maintenance of a closer relationship between the chomeland' and its diaspora. Adding onto her studies of post-colonial India, the case of 'bifurcated homeland' between the PRC and the ROC puts more emphasis on the core role of regime legitimacy as engendered by different normative underpinnings of the international system in during periods of time, and the subsequent changes in state-diaspora relations. Further research on the interplay between international system-level changes and domestic politics towards diaspora governance is needed to provide additional comparative analysis.

Furthermore, the bifurcation of the Chinese homeland and ensuing competition between rival regimes created an instance where there were strong mutual influences in 
both Beijing and Taipei's diaspora policy-making. Copying, mimicking, and even outbidding each other are key dynamics that form the micro-foundation of diaspora management. This paper thus contributes a different perspective to look at how diaspora policies are designed and implemented, as well as the nuances of their evolution over time (Délano Alonso and Mylonas 2019). Such a competitive logic and the ensuing mutual influence might be a more widespread phenomenon than the case presented here, and further research is needed for comparative studies of competitive diaspora policy-making.

\section{Notes}

1. The country changed its name from Burma to Myanmar in 1989. In this paper, I use Burma for the period before 1989, and Myanmar thereafter.

2. In the paper, I use Republic of China or ROC and Taiwan interchangeably. The same also applies to People's Republic of China or PRC and Mainland China.

3. Data were collected through interviews both during field trips in Thailand, Myanmar, Taiwan, as well as remotely via Internet during 2014 and 2016.

4. Here the term 'Chinese' usually refers to the current majority Han Chinese in China. There are many other ethnic groups who have relatively recent migration history from southern China to Southeast Asia as well, such as the mountainous Hmong (Miao) and the Iu Mien (Yao). These are often not included in the scholarly discussion as Chinese migration to Southeast Asia. However, most recently in PRC, as part of its domestic multi-ethnic politics, it started to include other non-Han Chinese ethnic groups who migrated out of China as overseas Chinese as well. For a discussion on this phenomenon, see (Barabantseva 2012).

5. http://www.newworldencyclopedia.org/entry/Overseas_Chinese.

6. http://www.stats.gov.cn/tjsj/tjgb/rkpcgb/qgrkpcgb/200204/t20020404_30316.html.

7. http://www.focat.org.tw/blog/?page_id=3.

8. For example in Thailand after the Phibun government passed the Anti Communism Act in 1952, many left-leaning Chinese were simply deported back to China (Chinvanno 1992).

9. There are several reasons why they stayed in Thailand. Some claim they stayed at the borderland because of a secret order of Chiang Kai-shek; while others claim there are factional fighting between the generals and the ones in Taiwan; and there are also others who speculate that the troops were benefiting handsomely from the opium trade across the Thai-Burmese border so there was no economic reason for them to go to Taiwan. Personal interviews, Taipei, September 2014, and Chiang Mai, June 2016.

10. Personal interviews, Taipei, September 2014.

11. http://www.ocac.gov.tw/OCAC/Eng/FAQ/List.aspx?nodeid=459\#.

12. http://www.mfa.gov.cn/chn//pds/wjdt/lsdt/t257001.htm.

13. Personal interviews, Chiang Mai, June 2016.

14. http://www.thaiwebsites.com/tourists-nationalities-Thailand-2015.asp.

\section{Acknowledgements}

I would like to thank the participants at the 'Migration, Mobility and Membership in a Globalizing World' workshop held at SOAS, University of London, on 26-27 July 2016 for their useful comments. I also would like to thank editors of this special issue, Harris Mylonas and Alexandra Délano Alonso, for their useful comments on different drafts of the paper.

\section{Disclosure statement}

No potential conflict of interest was reported by the author. 


\section{Funding}

The writing of this paper has been supported by the Leverhulme Trust Research Fellowship and British Council/Newton Fund.

\section{References}

Adamson, F. 2006. "Crossing Borders: International Migration and National Security." International Security 31 (1): 165-199.

Adamson, F. 2013. "Mechanisms of Diaspora Mobilization and the Transnationalization of Civil War.” In Transnational Dynamics of Civil War, edited by Jeffrey Checkel, 63-88. Cambridge: Cambridge University Press.

Adamson, F., and M. Demetriou. 2007. "Remapping the Boundaries of 'State' and 'National Identity': Incorporating Diasporas into IR Theorizing." European Journal of International Relations 13 (4): 489-526.

Appiah, K. A. 2007. Cosmopolitanism: Ethics in a World of Strangers. New York: W. W. Norton \& Company.

Armstrong, J. A. 1976. "Mobilized and Proletarian Diasporas." American Political Science Review 70 (02): 393-408.

Barabantseva, E. 2012. "Who Are 'Overseas Chinese Ethnic Minorities'? China's Search for Transnational Ethnic Unity.” Modern China 38 (1): 78-109. doi:10.1177/0097700411424565.

Bosniak, L. 2006. The Citizen and the Alien: Dilemmas of Contemporary Membership. Princeton: Princeton University Press.

Bresnan, J. 1994. From Dominoes to Dynamos: The Transformation of Southeast Asia. New York: Council on Foreign Relations.

Brinkerhoff, J. M. 2009. Digital Diasporas: Identity and Transnational Engagement. Cambridge: Cambridge University Press.

Brubaker, R. 1996. Nationalism Reframed: Nationhood and the National Question in the New Europe. Cambridge: Cambridge University Press.

Buzan, B. 2007. People, States \& Fear: An Agenda for International Security Studies in the Post-Cold War Era. Colchester: ECPR Press.

Chang, W. C. 2008. "The Interstitial Subjectivities of the Yunnanese Chinese in Thailand." The Asia Pacific Journal of Anthropology 9 (2): 97-122.

Chang, W. C. 2014. Beyond Borders: Stories of Yunnanese Chinese Migrants of Burma. Ithaca: Cornell University Press.

Chang, H. C., and R. Holt. 2014. Language, Politics and Identity in Taiwan: Naming China. London: Routledge.

Chen, J. 1994. "Shaking off an Historical Burden: China's Relations with the ASEAN-based Communist Insurgency in Deng's Era." Communist and Post-Communist Studies 27 (4): 443-462.

Chen, W. J. 2010. Tangle (Taibei Zhongguo Jie). Video. https://www.youtube.com/watch?v= zFe31GVP6fA.

Chin, P. 2003. Alias Chin Peng - My Side of History. Singapore: Media Masters.

Chinvanno, A. 1992. Thailand's Policies Towards China, 1949-54. Houndmills: Macmillan.

Chun, A. 1994. "From Nationalism to Nationalizing: Cultural Imagination and State Formation in Postwar Taiwan.” The Australian Journal of Chinese Affairs 31: 49-69.

Cohen, R. 1996. "Diasporas and the Nation-State: From Victims to Challengers." International Affairs 72 (3): 507-520.

Damm, J. 2012. “From 'Overseas Chinese' to 'Overseas Taiwanese'.” In Taiwanese Identity in the 21st Century: Domestic, Regional and Global Perspectives, edited by Gunter Schubert, and Jens Damm, 218-236. London: Routledge.

De Haas, H. 2010. "Migration and Development: A Theoretical Perspective." International Migration Review 44 (1): 227-264.

Délano Alonso, A., and A. Gamlen. 2014. "Comparing and Theorizing State-Diaspora Relations." Political Geography 41(July): 43-53. 
Délano Alonso, A., and H. Mylonas. 2019. “The Microfoundations of Diaspora Politics: Unpacking the State and Disaggregating the Diaspora." Journal of Ethnic and Migration Studies 45 (4): 473491. doi:10.1080/1369183X.2017.1409160.

Dittmer, L. 2004. “Taiwan and the Issue of National Identity.” Asian Survey 44 (4): 475-483.

Duan, Y. 2008. "Kuomintang Soldiers and Their Descendants in Northern Thailand: An Ethnographic Study." Journal of Chinese Overseas 4 (2): 238-257.

Eberstadt, N. 2010. Policy and Economic Performance in Divided Korea During the Cold War Era: 1945-91. Washington, DC: AEI Press.

Esman, M. 1986. “The Chinese Diaspora in Southeast Asia." In Modern Diasporas in International Politics, edited by Gabriel Shaffer, 130-163. Kent: Croom Helm.

Fitzgerald, S. 1972. China and the Overseas Chinese: A Study of Peking's Changing Policy: 19491970. Cambridge: Cambridge University Press.

Fludernik, M., ed. 2003. Diaspora and Multiculturalism: Common Traditions and New Developments. Amsterdam: Rodopi.

Gamlen, A. 2010. "The New Migration and Development Optimism: A Review of the 2009 Human Development Report." Global Governance: A Review of Multilateralism and International Organization 16 (3): 415-422.

Gamlen, A. 2013. “Creating and Destroying Diaspora Strategies: New Zealand's Emigration Policies Re-Examined." Transactions of the Institute of British Geographers 38 (2): 238-253.

Gamlen, A. 2014. "Diaspora Institutions and Diaspora Governance." International Migration Review 48(September): S180-S217.

Gamlen, A., M. E. Cummings, and P. M. Vaaler. 2019. "Explaining the Rise of Diaspora Institutions." Journal of Ethnic and Migration Studies 45 (4): 492-516. doi:10.1080/1369183X. 2017.1409163.

Gao, T. 2003. "Ethnic Chinese Networks and International Investment: Evidence from Inward FDI in China." Journal of Asian Economics 14 (4): 611-629.

Gries, P. H. 2004. China's New Nationalism: Pride, Politics, and Diplomacy. Berkeley: University of California Press.

Guan, A. C. 2001. “The Domino Theory Revisited: The Southeast Asia Perspective.” War \& Society 19 (1): 109-130.

Hannerz, U., and K. Goldmann. 2000. Nationalism and Internationalism in the Post-Cold War Era. New ed. London: Routledge.

Hartig, F. 2012. "Confucius Institutes and the Rise of China." Journal of Chinese Political Science 17 (1): $53-76$.

Hartig, F. 2016. "How China Understands Public Diplomacy: The Importance of National Image for National Interests." International Studies Review, June. doi:10.1093/isr/viw007.

Hesse, B., and S. Sayyid, eds. 2000. Un/Settled Multiculturalisms: Diasporas, Entanglements, Transruptions. 1st ed. London: Zed Books.

Hill, A. M. 1998. Merchants and Migrants: Ethnicity and Trade among Yunnanese Chinese in Southeast Asia. . New Haven, CT: Yale University Southeast Asia Studies.

Ho, E. L. 2011. "Claiming' the Diaspora: Elite Mobility, Sending State Strategies and the Spatialities of Citizenship.” Progress in Human Geography 35 (6): 757-772.

Hoare-Vance, S. 2010. The Confucius Institutes and China's Evolving Foreign Policy. Saarbrücken, Germany: LAP LAMBERT Academic.

Huang, S. M. 2010. Reproducing Chinese Culture in Diaspora: Sustainable Agriculture and Petrified Culture in Northern Thailand. Lanham. Boulder: Lexington Books.

Hughes, C. R. 1997. Taiwan and Chinese Nationalism: National Identity and States in International Society. London: Routledge.

Hughes, C. 2011. "Negotiating National Identity in Taiwan: Between Nativisation and DeSinicisation." In Taiwan's Democracy: Economic and Political Challenges, edited by Robert Ash, John Garver, and Penelope Prime, 51-74. London: Routledge. Routledge Research on Taiwan Series.

Itzigsohn, J. 2000. "Immigration and the Boundaries of Citizenship: The Institutions of Immigrants' Political Transnationalism.” International Migration Review 34 (4): 1126-1154. 
Joppke, C. 1999. “Citizenship Between De- and Re-Ethnicization.” European Journal of Sociology 44 (03): 429-458.

Koinova, M. 2009. "Diasporas and Democratization in the Post-Communist World." Communist and Post-Communist Studies 42 (1): 41-64.

Kurlantzick, J. 2007. Charm Offensive: How China's Soft Power is Transforming the World. New Haven: Yale University Press.

Lardy, N. R. 1994. China in the World Economy. Washington, D.C.: Peterson Institute for International Economics.

Lee, S. T., and J. F. Williams, eds. 2014. Taiwan's Struggle: Voices of the Taiwanese. London: Rowman \& Littlefield.

Levitt, P., and R. de la Dehesa. 2003. "Transnational Migration and the Redefinition of the State: Variations and Explanations." Ethnic and Racial Studies 26 (4): 587-611.

Low, C. C. 2013. "Taiwanese and German Citizenship Reforms: Integration of Immigrants Without Challenging the Status Quo, 1990-2000.” European Journal of East Asian Studies 12: 269-294.

Mahieu, R. 2019. “'We're Not Coming From Mars; We Know How Things Work in Morocco!' How diasporic Moroccan Youth Resists Political Socialisation in State-Led Homeland Tours." Journal of Ethnic and Migration Studies 45 (4): 674-691. doi:10.1080/1369183X.2017.1409177.

Makeham, J., and A. Hsiau. 2005. Cultural, Ethnic, and Political Nationalism in Contemporary Taiwan: Bentuhua. New York: Palgrave Macmillan.

McConnell, F. 2012. "Governmentality to Practise the State? Constructing a Tibetan Population in Exile." Environment and Planning D: Society and Space 30 (1): 78-95.

Metzler, J. J. 2014. Divided Dynamism: The Diplomacy of Separated Nations: Germany, Korea, China. Lanham: University Press of America.

Mullings, B. 2012. "Governmentality, Diaspora Assemblages and the Ongoing Challenge of 'Development'." Antipode 44 (2): 406-427.

Mylonas, H. 2013. The Politics of Nation Building: Making Co-Nationals, Refugees, and Minorities. New York: Cambridge University Press.

Niou, E. M. S. 2004. "Understanding Taiwan Independence and Its Policy Implications." Asian Survey 44 (4): 555-567.

Nyíri, P. 1997. "Reorientation: Notes on the Rise of the PRC and Chinese Identities in Southeast Asia." Asian Journal of Social Science 25 (2): 161-182.

Nyíri, P. 2006. “The Yellow Man’s Burden: Chinese Migrants on a Civilizing Mission.” The China Journal 56: 83-106.

Olson, J. S., and R. W. Roberts. 2013. Where the Domino Fell: America and Vietnam 1945-2010. 6th ed. Chichester, West Sussex: Wiley-Blackwell.

Oyen, M. 2010. "Communism, Containment and the Chinese Diaspora." In The Cold War in Asia: The Battle for Hearts and Minds, edited by Yangwen Zheng, Hong Liu, and Michael Szonyi, 5994. Boston: Brill.

Panagiotidis, J. 2015. "What Is the German's Fatherland? The GDR and the Resettlement of Ethnic Germans from Socialist Countries (1949-1989).” East European Politics and Societies 29 (1): 120-146. doi:10.1177/0888325414540934.

Parreñas, R. S., and L. Siu, eds. 2007. Asian Diasporas: New Formations, New Conceptions. Stanford: Stanford University Press.

Ragazzi, F. 2009. “Governing Diasporas.” International Political Sociology 3 (4): 378-397.

Ragazzi, F. 2014. “A Comparative Analysis of Diaspora Policies.” Political Geography 41(July): 7489.

Rigger, S. 2002. "Nationalism Versus Citizenship in the Republic of China on Taiwan." In Changing Meanings of Citizenship in Modern China, edited by Merie Goldman, and Elizabeth Perry, 353374. Cambridge, MA: Harvard University Press.

Safran, W. 1991. "Diasporas in Modern Societies: Myths of Homeland and Return." Diaspora: A Journal of Transnational Studies 1 (1): 83-99.

Seagrave, S. 2010. Lords of the Rim 2010: The Invisible Empire of the Overseas Chinese. Scotts Valley, CA, United States: Createspace. 
Shain, Y. 2008. Kinship and Diasporas in International Affairs. Ann Arbor: University of Michigan Press.

Shao Dan, W. 2009. "Chinese by Definition: Nationality Law, Jus Sanguinis, and State Succession, 1909-1980." Twentieth-Century China 35 (1): 4-28.

Siriphon, A. 2016. "The Qiaoban, The PRC Influence and Nationalist Chinese in Northern Thai Borderland.” International Journal of Asian Studies 13 (1): 1-17.

Skinner, G. W. 1957. Chinese Society in Thailand an Analytical History. ACLS Humanities E-Book. Ithaca, NY: Cornell University Press.

Skrbis, Z. 1999. Long-Distance Nationalism: Diasporas, Homelands and Identities. Brookfield: Routledge.

Smart, A., and J. Y. Hsu. 2004. "The Chinese Diaspora, Foreign Investment and Economic Development in China." The Review of International Affairs 3 (4): 544-566.

Smith, R. C. 2003. "Diasporic Memberships in Historical Perspective: Comparative Insights from the Mexican, Italian and Polish Cases.” International Migration Review 37 (3): 724-759.

Stevenson, P. 2001. Language and German Disunity: A Sociolinguistic History of East and West in Germany, 1945-2000. Oxford: Oxford University Press.

Suryadinata, L. 2007. Understanding the Ethnic Chinese in Southeast Asia. Singapore: Institute of Southeast Asian Studies.

To, J. J. H. 2014. Qiaowu: Extra-Territorial Policies for the Overseas Chinese. Leiden: Brill Academic. Varadarajan, L. 2010. The Domestic Abroad: Diasporas in International Relations. New York: Oxford University Press.

Wang, G. 1991. China and the Chinese Overseas. Singapore: Times Academic Press.

Wang, Z. 2008. "National Humiliation, History Education, and the Politics of Historical Memory: Patriotic Education Campaign in China." International Studies Quarterly 52 (4): 783-806.

Wang, J. S. H. 2011. "In the Name of Legitimacy: Taiwan and Overseas Chinese During the Cold War Era." The China Review: An Interdisciplinary Journal on Greater China 11 (2): 65-90.

Weiss, J. C. 2014. Powerful Patriots: Nationalist Protest in China's Foreign Relations. New York: Oxford University Press.

Wong, T. H. 2016. "College Admissions, International Competition, and the Cold War in Asia: The Case of Overseas Chinese Students in Taiwan in the 1950s." History of Education Quarterly 56 (2): 331-357.

Zhao, S. 1998. "A State-Led Nationalism: The Patriotic Education Campaign in Post-Tiananmen China." Communist and Post-Communist Studies 31 (3): 287-302.

Zhuang, G. 1998. "The Policies of the Chinese Government Towards Overseas Chinese (19491966)." In The Chinese Diaspora: Selected Essays. Vol. 1., edited by Ling-chi Wang, and Gungwu Wang, 14-28. Singapore: Times Academic Press. 